BRITISH POLITICAL IDEOLOGIES 


\section{CONTEMPORARY POLITICAL STUDIES SERIES}

Series Editor: John Benyon, Director, Centre for the Study of Public Order, University of Leicester

A series which provides authoritative yet concise introductory accounts of key topics in contemporary political studies.

Other titles in the series include:

Pressure Groups, Politics and Democracy in Britain, 2nd edition WYN GRANT, University of Warwick

UK Political Parties since 1945

Edited by ANTHONY SELDON, Institute of Contemporary British

History

Politics and Policy Making in Northern Ireland

MICHAEL CONNOLLY, University of Ulster

Local Government and Politics in Britain

JOHN KINGDOM, Sheffield Hallam University

British Political Parties

JUSTIN FISHER, London Guildhall University

British Government: The Central Executive Territory

PETER MAdGwick, Professor Emeritus, Oxford Brookes University

Race and Politics in Britain

SHAMIT SAGGAR, Queen Mary and Westfield College, University of

London

Selecting the Party Leader

MALCOLM PUNNETT, University of Strathclyde

Does Parliament Matter?

PHILIP NORTON, University of Hull

The President of the United States

DAVID MERVIN, University of Warwick

The Politics of Economic Policy

WYN GRANT, University of Warwick

Introduction to International Politics

DEREK HEATER, formerly of Brighton University and

G.R. BERRIDGE, University of Leicester

Elections and Voting Behaviour in Britain, 2nd edition

DAVID DENVER, Lancaster University

The Law and Politics of the British Constitution of the United

Kingdom

PETER MADGWICK and DIANA WOODHOUSE, Oxford Brookes

University 


\title{
BRITISH POLITICAL IDEOLOGIES
}

\author{
Second edition
}

ROBERT LEACH

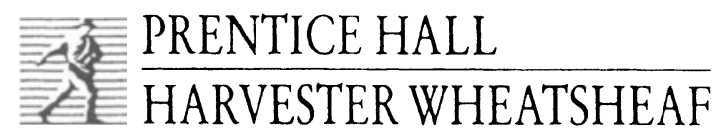

LONDON NEW YORK TORONTO SYDNEY TOKYO SINGAPORE MADRID MEXICOCITY MUNICH 
First published 1996 by

Prentice Hall Europe

Campus 400, Maylands Avenue

Hemel Hempstead

Hertfordshire, HP2 7EZ

A division of

Simon \& Schuster International Group

(c) Prentice Hall Europe 1996

All rights reserved. No part of this publication may be reproduced, stored in a retrieval system, or transmitted, in any form, or by any means, electronic, mechanical, photocopying, recording or otherwise, without prior permission, in writing, from the publisher.

Typeset in 10/12 pt Times

by Photoprint, Torquay, Devon

Library of Congress Cataloging-in-Publication Data

\section{Leach, Robert.}

British political ideologies / Robert Leach. - 2nd ed. p. $\quad \mathrm{cm}$. - (Contemporary political studies series)

Includes bibliographical references and index.

ISBN 978-0-13-518176-8 (alk. paper)

1. Political science - Great Britain. 2. Right and left (Political science) I. Title. II. Series: Contemporary political studies series (Prentice Hall)

JA84.G7L39 1996

320.5' $0941-\mathrm{dc} 20$

British Library Cataloguing in Publication Data

A catalogue record for this book is available from the British Library

ISBN 978-0-333-73917-4 ISBN 978-1-349-14909-4 (eBook) DOI 10.1007/978-1-349-14909-4
$\begin{array}{llll}2 & 3 & 4 & 5\end{array}$
$\begin{array}{lll}00 & 99 \quad 98\end{array}$
97 


\section{CONTENTS}

Preface to first edition $\quad$ ix

Preface to second edition $\quad$ xi

I IDEOLOGICAL DIFFERENCE AND CONSENSUS IN BRITAIN SINCE 1945

Introduction

Consensus and the end of ideology?

The neglect of political ideas 5

The rebirth of ideology 6

From ideological polarisation to a new consensus $\quad 10$

Conclusion 13

$\begin{array}{ll}\text { Guide to further reading } & 14\end{array}$

2 IDEOLOGY 15

Introduction $\quad 15$

What is ideology? $\quad 15$

Classifying ideologies $\quad 20$

Constituents of ideologies 23

Levels of ideology 27

Power, influence and indoctrination 29

Theory and reality - ideology and public policy 32

Objectivity and bias in the study of ideologies 33

Guide to further reading 36 
3 THE BRITISH POLITICAL TRADITION 37

Introduction 37

Why British political ideologies? 38

The impact of the Reformation and religious upheavals of the sixteenth century $\quad 40$

The English Civil War and the Glorious Revolution 44

The British Constitution and the British political tradition 50

The impact of industrialisation - interests and power 53

The impact of industrialisation - laissez-faire and collectivism 56

The impact of war 59

The legacy of empire 61

Conclusion $\quad 64$

Guide to further reading $\quad 64$

4 LIBERALISM 66

Introduction $\quad 66$

Interpretations of liberalism $\quad 68$

Liberalism: underlying assumptions $\quad 70$

$\begin{array}{ll}\text { The Whig tradition } & 73\end{array}$

Radicals $\quad 76$

Classical economics and utilitarianism $\quad 79$

Victorian liberalism $\quad 82$

Liberalism, capitalism and democracy $\quad 86$

The New Liberalism $\quad 89$

Neo-liberalism $\quad 94$

Liberalism today $\quad 95$

Guide to further reading $\quad 98$

5 CONSERVATISM 100

Introduction 100

The Tory tradition $\quad 103$

$\begin{array}{ll}\text { Reaction and gradualism } & 104\end{array}$

Suspicion of reason $\quad 109$

Human nature $\quad 112$

Authority, leadership and Tory democracy 114

$\begin{array}{ll}\text { The defence of property } & 116\end{array}$

$\begin{array}{ll}\text { Paternalism and collectivism } & 118\end{array}$

$\begin{array}{ll}\text { Protection and Tory collectivism } & 120\end{array}$

Patriotism and imperialism 123

$\begin{array}{lr}\text { Conservatism and Thatcherism } & 125\end{array}$ 
Conservatism and post-Thatcherism

Guide to further reading

6 LABOURISM AND SOCIALISM

Introduction

Socialist values

Evolutionary and revolutionary socialism

The rise of the industrial working class in nineteenth-century Britain

Marxism and the British labour movement

Trade unionism and labourism

The Labour Party and socialism

State socialism and alternatives to state socialism $\quad 156$

Labour in power? MacDonaldism 159

Labour in power - the Attlee government $\quad 160$

Revisionism, pragmatism and fundamentalism 163

$\begin{array}{ll}\text { Democratic socialism and social democracy } & 167\end{array}$

New Labour? 168

British socialism and the wider world $\quad 172$

$\begin{array}{ll}\text { Guide to further reading } & 173\end{array}$

7 THE FAR LEFT AND THE FAR RIGHT 175

$\begin{array}{ll}\text { Introduction } & 175\end{array}$

$\begin{array}{ll}\text { The far left } & 177\end{array}$

Communism $\quad 179$

Trotskyism and revolutionary socialism $\quad 182$

Anarchism $\quad 185$

$\begin{array}{ll}\text { The far left and the Labour left } & 187\end{array}$

The far right $\quad 188$

Fascism and the far right 189

Fascism in Britain - Oswald Mosley 192

The far right in modern Britain 193

A neo-Nazi revival? 196

$\begin{array}{ll}\text { Guide to further reading } & 197\end{array}$

8 NATIONALISM 198

Introduction $\quad 198$

What is nationalism? 200

Why nationalism developed $\quad 202$

How nationalism has developed - revolutionary and liberal nationalism 
Conservative nationalism and imperialism 207

Nationalism, anti-colonialism and socialism 211

$\begin{array}{ll}\text { English and British nationalism } & 213\end{array}$

$\begin{array}{ll}\text { Scottish and Welsh nationalism } & 217\end{array}$

Europe, regionalism and nationalism $\quad 224$

Globalisation and the future of nationalism 227

Guide to further reading $\quad 230$

9 FEMINISM 23I

Introduction 231

The origins and development of feminist thought liberal feminism 233

Socialist and Marxist feminism $\quad 238$

Radical feminism 243

Eco-feminism $\quad 249$

The impact of the New Right - conservative feminism? 252

Feminism and post-modernism 256

Feminism and the future $\quad 257$

Guide to further reading $\quad 259$

10 GREEN IDEOLOGY 261

Introduction 261

Green and other ideologies $\quad 263$

Greens and the right $\quad 264$

Greens and the left $\quad 265$

Key elements of Green thinking $\quad 266$

Limits to growth - sustainability $\quad 267$

Ecocentrism $\quad 269$

The holistic approach $\quad 272$

Small is beautiful? $\quad 273$

Green strategy $\quad 276$

Guide to further reading $\quad 282$

$\begin{array}{ll}\text { Bibliography } & 285\end{array}$

$\begin{array}{ll}\text { Index } & 297\end{array}$ 


\section{PREFACE TO FIRST EDITION}

This book provides a simple introduction to the extremely complex and controversial subject of British political ideologies. It is intended primarily for both undergraduates and A level students, although hopefully it will also interest any intelligent layperson who desires to know more about liberalism, socialism, conservatism and other political creeds.

The scope and breadth of the book inevitably requires a somewhat brief and perhaps over-simplified treatment of great themes and complex ideas. Moreover, although I have tried to be as dispassionate and detached as possible in discussing a wide range of sharply opposed viewpoints, it is only too likely that my interpretation of some ideologies will be seen as partial or narrow. I can only repeat that this book is intended as an introductory text. Those who seek further illumination are advised to delve more deeply into the extensive literature on political ideas, some of which is indicated in the bibliography.

I would like to thank John Benyon, the series editor, and Clare Grist of Philip Allan for their help and advice. Several colleagues at Leeds Polytechnic have read part of the manuscript, and I would like to thank in particular Brendan Sheehan and Janie Percy-Smith for their detailed and constructive advice. I also owe a debt to my students, particularly on the BA Economics and Public Policy degree, for sharpening my ideas.

I would also like to acknowledge a few longer-term debts - to my late mother, and my father, for the support they gave to my education, 
and my shifting, eccentric academic pursuits, and to my old history teacher, Michael Cherniavsky, who first stimulated my interest in political ideas and much else besides. My greatest debt is, however, to my wife, Judith, without whose constant encouragement and support this book would certainly never have been written. 


\section{PREFACE TO SECOND EDITION}

A commission for a second edition is gratifying to an author's pride, but carries little additional academic kudos. Had I realised how much work would be involved I might not have agreed to it so readily. Those familiar with the original book will notice several changes. There are three completely new separate chapters on nationalism, feminism and the Greens, various other additional sections and diagrams, as well as some necessary updating to take account of developments in the last few years. I have also taken the opportunity to undertake some restructuring of material, for example on the chapter on labourism and socialism. As a result it is now a considerably bigger book; whether it is a better book I leave my readers to decide. The debts I acknowledged in the preface to the first edition still apply, although sadly Michael Cherniavsky has since died. For this revised version I owe particular thanks to my colleague Janie Percy-Smith, who gave valuable advice for the material on feminism (although convention requires that I acquit her of any blame for the final result), the anonymous reviewer of an early draft of my chapters on the Greens, and all at Prentice Hall, including Clare Grist (who inveigled me into undertaking the revision), Ruth Pratten, and Ian MacQuarrie. My greatest debt is, however, once more to my wife, Judith. 